\title{
Secondary Metabolites in Flax Root Extracts at Various Stages of Maturity and Effects on Proliferation and Cytotoxicity in Oestrogen-Receptor-Positive Breast Cancer Cells
}

\author{
Marlen Szewczyk ${ }^{1}$, Nicole Strater ${ }^{1}$, André Schlichting², Volker Briese ${ }^{1}$, \\ Dagmar-Ulrike Richter ${ }^{1}$ \\ ${ }^{1}$ Department of Obstetrics and Gynaecology, Faculty of Medicine, University of Rostock, Rostock, Germany \\ ${ }^{2}$ Institute for Land-Use, Faculty of Agricultural and Environmental Sciences, University of Rostock, Rostock, \\ Germany \\ Email: marlen.szewczyk@uni-rostock.de
}

Received 25 January 2014; revised 4 March 2014; accepted 12 March 2014

Copyright (C) 2014 by authors and Scientific Research Publishing Inc.

This work is licensed under the Creative Commons Attribution International License (CC BY).

http://creativecommons.org/licenses/by/4.0/

(c) (i) Open Access

\begin{abstract}
Flax contains large amounts of hormone-like compounds, especially lignans. These so-called phytoestrogens are thought to inhibit the cell growth of hormone-sensitive cancers. Hence, we analysed the influence of flax root extracts at various stages of maturity on the proliferation and cytotoxicity in oestrogen-receptor-positive breast cancer cells (MCF7) in vitro. Flax root extracts were prepared by using lignan extraction. The extracted compounds were analysed by Pyrolysis-Field Ionisation Mass Spectrometry. Various extract concentrations were applied to the cells to test for proliferation (BrdU test) and cytotoxicity (LDH test). A significantly higher inhibition of cell proliferation was observed with an extract made from 9-week-old flax roots in comparison with that of 3- and 6-week-old roots. Older roots contained more lignans and other phenolic substances than younger roots. The maturity grade of plants or their various parts is thus important for the production and concentration of secondary metabolites and leads to different biological effects on breast cancer cell growth.
\end{abstract}

Keywords

Flax Root; Stage of Maturity; Lignans; Breast Cancer; MCF7 


\section{Introduction}

Cases of mammary gland carcinoma have been increasing continuously for years. In addition to traditional approaches in oncological pharmacology and surgery, great interest has been shown in the development of new avenues in the prevention and therapy of breast cancer.

Cases of hormone-dependent carcinoma are significantly lower in regions with a traditional diet high in phytoestrogens than in regions with minor intake. The outstanding constituents in the group of phytoestrogens are isoflavones and lignans, which are structurally similar to endogen oestrogens and have the ability to bind to the human oestrogen-receptors alpha and beta [1]. Phytoestrogens, especially isoflavones, have been identified in large amounts in soy [2]. Hence, native plants have been sought with a high content of isoflavones and lignans. One such native plant rich in phytoestrogens is flax, Linum usitatissimum [3], which is an agricultural plant that has spread widely for centuries. It is used especially for the production of textiles and plant oil. Linum usitatissimum is an annual plant reaching a height of up to more than $200 \mathrm{~cm}$. Anthesis is between July and August; the main growth phase is in May and June. The plant does not make great demands on soil and thus it can be easily cultivated [4]-[6].

Prior to this study, we have been able to demonstrate a difference in cancer cells with regard to the effects of extracts from the leaves, stems and roots of Linum usitatissimum. Our results have indicated that root extract is more effective than leaf and stem extracts [7].

In this study, we wished to determine any influences on the proliferation and cytotoxicity of breast cancer cells depending on the stage of maturity of the flax roots and the differences in the chemical composition of their extracts.

\section{Material and Methods}

\subsection{Preparation of an Ethanolic Extract from Flax Roots (L. usitatissimum)}

The plants were sown under field conditions and harvested at intervals of three weeks. Based on these conditions, three different stages of maturity could be used for the study: roots at 9 weeks (9 w), 6 weeks $(6 \mathrm{w})$ or 3 weeks (3 w). The extracts were prepared according to Luyengi et al. [8] as modified by Matscheski et al. [9]. Plant material (20 g) was ground with liquid nitrogen in a mortar and extracted with $180 \mathrm{ml}$ of $100 \%$ methanol in a water bath $\left(15 \mathrm{~min}, 70^{\circ} \mathrm{C}\right)$ by using a reflux condenser. The solution was cooled, filtered and evaporated almost to dryness. The extract was resuspended in $8 \mathrm{ml}$ distilled water and partitioned with ethyl acetate. After being dried, the ethyl-acetate-soluble fraction was dissolved in absolute ethanol to provide a stock solution of $100 \mathrm{mg} / \mathrm{ml}$. For cell culture tests, this solution was diluted to the following final concentrations: 1000, 500, 100, 50, 10, 1, 0.1 and $0.01 \mu \mathrm{g} / \mathrm{ml}$.

\subsection{Pyrolysis-Field Ionisation Mass Spectrometry (Py-FIMS)}

By using Py-FIMS, we were able to analyse the components of the root extracts [10]. An aliquot of $5 \mu \mathrm{l}$ of the extract was transferred to a quartz crucible. With an applied heating rate of $6.66 \mathrm{~K}$ per scan, the biological macromolecules in the extract were fragmented into their chemical subunits. This thermal evaporation occurred rapidly and with a minimal mass of substance. The fragments were correlated with the known structure of substances of interest. The molecular fragments of the thermal degradation was ionised in the following high electric field (FI Emitter $+4.8 \mathrm{kV}$, Counter electrode $-5.5 \mathrm{kV}$ ). The gaseous ions were accelerated, separated, electrically intensified and registered in a Finnigan MAT 900 mass spectrometer. During the heating period from $110^{\circ} \mathrm{C}$ to $700^{\circ} \mathrm{C}$ and the period of analysis of 12 minutes, 91 mass spectra at an interval from 50 to 700 Dalton were registered and recorded in a data system. For each of the single scans, the absolute and relative ion intensities of 14 classes of chemical compounds were calculated by summation of the ion intensities of 4 to 127 indicator signals. The marker signal selection was based on the concepts of Schulten et al. [11], Hempfling et al. [12] and Hempfling and Schulten [13]. Adaptation and validation of a linum-based mass spectrometric database were achieved by an exhaustive literature survey with tentative assignments and the measurement of selected pure compounds. This procedure was carried out for each of three replicate measurements per sample. The results were averaged for statistical analyses.

\subsection{Cell Culture and Treatment}

The human breast cancer cell line MCF7 was obtained from the Department of Human and Animal Cell Culture, 
Braunschweig, Germany. Cells were cultivated in Dulbecco's modified Eagle's medium (DMEM, Sigma-Aldrich-Chemie, Germany). This medium was supplemented with 4.5\% glucose; L-glutamine; 2.6 g/l HEPES pH 7.4; $3.0 \mathrm{~g} / \mathrm{NaHCO}_{3} ; 10 \%$ foetal calf serum; $1 \%$ penicillin; $1 \%$ streptomycin and $0.5 \%$ amphotericin $\mathrm{B}$. The MCF7 cell line was cultured in an incubator under physiological conditions $\left(37^{\circ} \mathrm{C} ; 5 \% \mathrm{CO}_{2}\right.$, humidified atmosphere).

\subsection{Detection of Cytotoxicity and Proliferation}

For proliferation and cytotoxicity tests, a cell concentration of $5 \times 10^{5}$ cells/ml was used. The breast cancer cells (100 $\mathrm{\mu l} /$ well) were plated onto 96-well micro-plates. After 24 hours, the flax root extracts at different concentrations $(0.01 \mu \mathrm{g} / \mathrm{ml}-1000 \mu \mathrm{g} / \mathrm{ml})$ and all controls were added. $17 \beta$-oestradiol and tamoxifen (anti-oestrogen) were used as positive controls (final concentrations: $50 \mu \mathrm{g} / \mathrm{ml} ; 1 \mu \mathrm{g} / \mathrm{ml} ; 0.1 \mu \mathrm{g} / \mathrm{ml}$ ). Both controls were commercially acquired from Sigma (Germany). One of the negative controls was the solvent ethanol (Roth; Germany), the other one being the untreated MCF7 cell suspension.

For measuring cytotoxicity, the Cytotoxicity Detection Kit LDH (Roche Diagnostics, Germany) and, for cell proliferation, the BrdU assay (colorimetric, Roche Diagnostics) were used according the manufacturer's protocol.

\subsection{Statistical Analysis}

Cell culture tests were performed in quadruplicate and repeated at least four times. Statistical analysis was executed by using the Student's $t$-test for a comparison of the means. Data are presented as means \pm standard deviation. All values with $P \leq 0.01$ differ significantly from the negative control (ethanol) and are denoted with an asterisk $\left({ }^{*}\right)$. Significance between different stages of maturity $(P \leq 0.05)$ is symbolised with a hatch sign $\left({ }^{*}\right)$.

\section{Results}

\subsection{Pyrolysis-Field Ionisation-MS}

Py-FIMS allowed the characterisation of substance classes in the extracts being tested. The analysis showed a high fraction of free saturated and unsaturated fatty acids. Sterols and triterpenes were detected in all three stages, but their total ion intensity (TII) was higher in $3 \mathrm{w}$ than in $6 \mathrm{w}$ and $9 \mathrm{w}$ extracts (Figure 1).

The lignan fraction (0.3\%) in $3 \mathrm{w}$ extracts was striking. Phenols and lignin/lignan monomers were verified, as were lignin dimers. In the 6-week-old flax root, we detected lignans (2.2\%), lignin dimers, phenols and lignin/

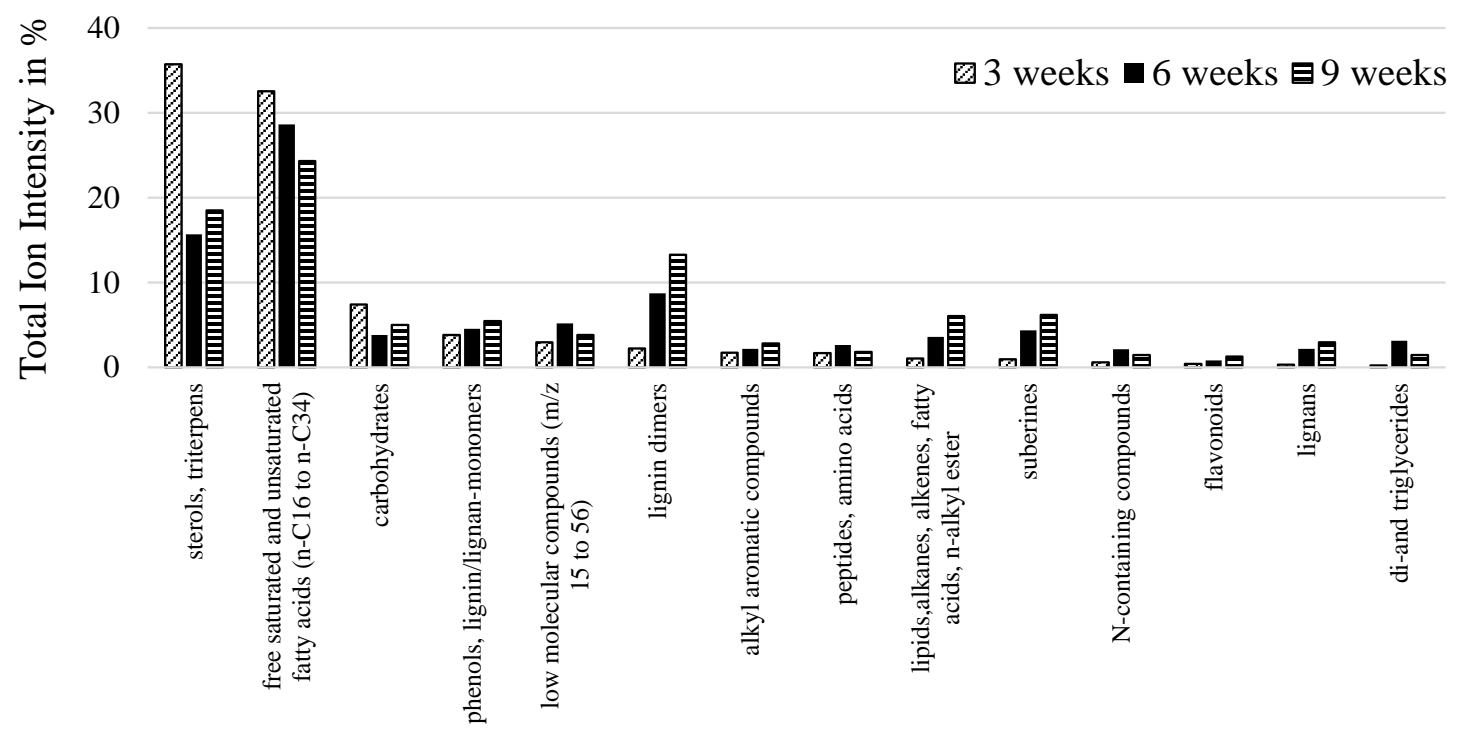

Figure 1. Pyrolysis field ionisation mass spectrometry: Data represent the relative abundance of the total ion intensity (\% TII) of 14 substance classes in root extracts at various stages of maturity from Linum usitatissimum. 
lignan monomers. The $9 \mathrm{w}$ root showed the highest TII of lignans (3\%) and lignin dimers but the proportion of fatty acids was the lowest compared with the other two stages. Flavonoids were also found in all three flax roots, increasing with the maturity of the flax $(0.4 \%, 0.8 \%$ and $1.3 \%)$. The percentage of groups of phenolic compounds, potentially containing phytoestrogens, was much higher in the extract of the $9 \mathrm{w}(23 \%)$ root than in $6 \mathrm{w}$ (16.3\%) and $3 \mathrm{w}(6.8 \%)$ roots.

Figure 2 illustrates the thermograms of total ion intensity (inset upper right) and summed averaged Py-FI mass spectra of the flax root extracts. At first glance, all depict similar patterns. However, on closer inspection, differences can be noted. The thermograms at $3 \mathrm{w}$ (Figure 2(a)) and $9 \mathrm{w}$ (Figure 2(c)) had clear multimodal curvature, indicating fractions of different thermal stability. The first volatilization maximum for $3 \mathrm{w}$ occurred at $200^{\circ} \mathrm{C}$. The same was detected for $6 \mathrm{w}$ roots (Figure 2(b)) but without a clear peak and without further curves. The thermogram of the $9 \mathrm{w}$ root had a maximum in the range $130^{\circ} \mathrm{C}$ to $180^{\circ} \mathrm{C}$ and a second around $250^{\circ} \mathrm{C}$ to $300^{\circ} \mathrm{C}$. The maximum intensities were different and increased with the age of the roots. The signal patterns of the summed Py-FI mass spectra also behaved differently, with masses $\mathrm{m} / \mathrm{z}>500$ at $6 \mathrm{w}$; these were lower or not pronounced in the other two root groups. However, we also found that the same mass signals differed in their TII (e.g. 180, 248, 256, 280 340, 400 and 414). The mass spectra and thermograms at $3 \mathrm{w}$ and $9 \mathrm{w}$ seemed similar.
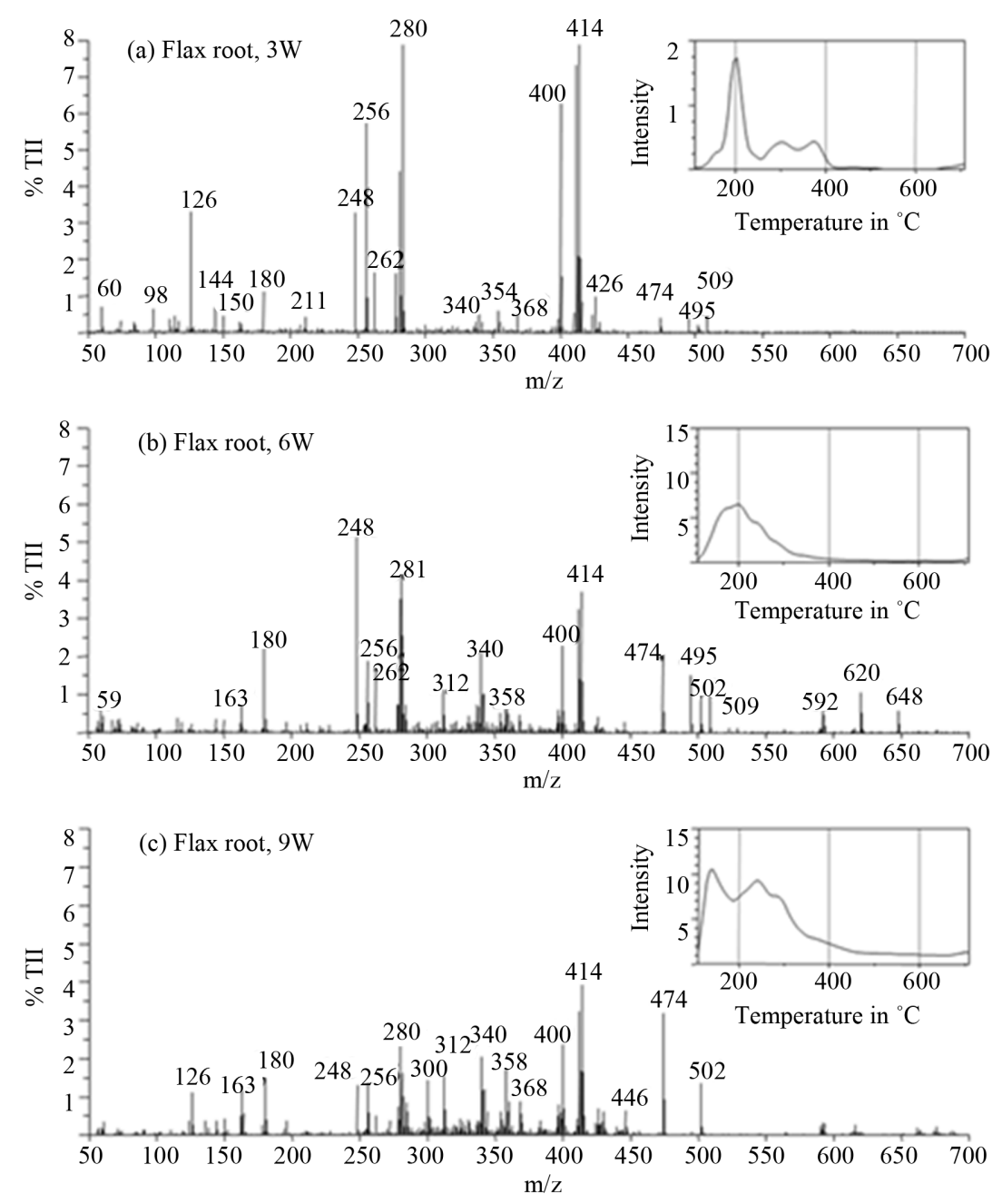

Figure 2. Thermograms of total ion intensity (TII) (insets upper right) and summed averaged pyrolysis-field ionisation mass spectra of flax root extracts ( $L$. usitatissimum) taken at various stages of maturity: (a) 3-week-old root; (b) 6-week-old root; (c) 9-week-old root. 


\subsection{Influence on MCF7 Cell Growth}

A significant cytotoxic effect was detected for all three stages of maturity at the highest extract concentration $(1000 \mu \mathrm{g} / \mathrm{ml})$. The extracts of $3 \mathrm{w}$ and $9 \mathrm{w}$ roots caused a cytotoxicity of more than $50 \%$. For the concentrations of $500 \mu \mathrm{g} / \mathrm{ml}$, a cytotoxicity of about $35 \%$ was determined. At other concentrations, no cytotoxic effect was measured (Figure 3). A comparison between the three stages of maturity showed statistical significance for 3 $\mathrm{w} / 6 \mathrm{w}(1000,100$ and $0.01 \mu \mathrm{g} / \mathrm{ml})$ and $3 \mathrm{w} / 9 \mathrm{w}(0.01 \mu \mathrm{g} / \mathrm{ml})$.

In addition to cytotoxicity, the influence of extracts on cell proliferation was of interest (Figure 4). Cell proliferation was significantly inhibited at high concentrations of all three extracts in an age-dependent manner. The $9 \mathrm{w}$ root extract decreased cell growth by up to $50 \%$, the $6 \mathrm{w}$ extract by up to $40 \%$ and the $3 \mathrm{w}$ extract by up to $15 \%$. Incubation of the cells with extracts at $100 \mu \mathrm{g} / \mathrm{ml}$ and $50 \mu \mathrm{g} / \mathrm{ml}$ resulted in an inhibition of nearly $15 \%$ (6 $\mathrm{w}$ and $9 \mathrm{w})$. A significant difference as noted between $3 \mathrm{w}$ and $9 \mathrm{w}(100$ and $500 \mu \mathrm{g} / \mathrm{ml})$ and $3 \mathrm{w} / 6 \mathrm{w}(100$ $\mu \mathrm{g} / \mathrm{ml}$ ). At low concentrations (1, 0.1 and $0.01 \mu \mathrm{g} / \mathrm{ml}$ ), the extract of the 3-week-old flax root promoted cell proliferation to $130 \%$. In the case of $0.01 \mu \mathrm{g} / \mathrm{ml}$, this was statistically significant compared with the results of $6 \mathrm{w}$ extract. The other stages of maturity did not show this proliferating influence.

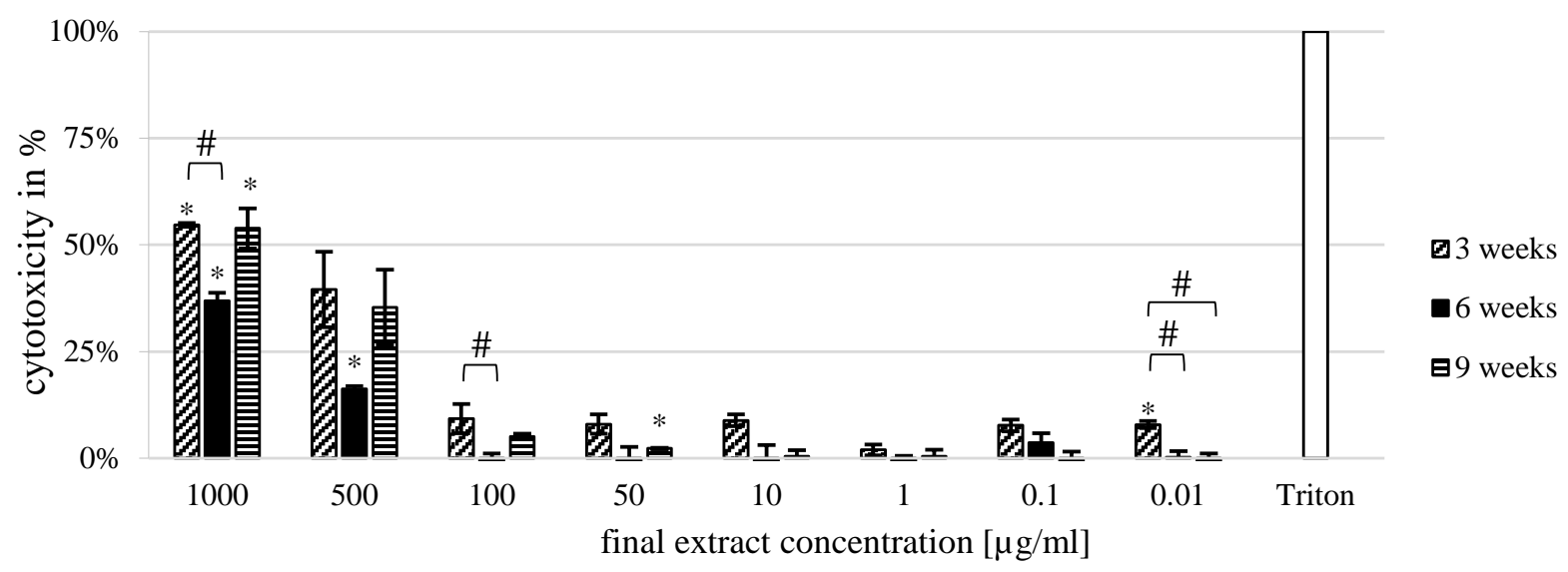

Figure 3. Effect of various concentrations of root extracts from Linum usitatissimum at various stages of maturity on cytotoxicity (LDH test) of the MCF7 cell line. Data (mean \pm SD) represent relative cytotoxicity in \% in comparison with a negative ethanol control $(0 \%)$ and Triton X-100 control $(100 \%)$ and were obtained in at least 4 experiments. Asterisks $\left(^{*}\right)$ indicate significant differences between treated cells and the negative control $(P \leq 0.01)$. Hatch signs $\left(^{\#}\right)$ indicate significant differences between the same concentrations of two root extracts $(P \leq 0.05)$.

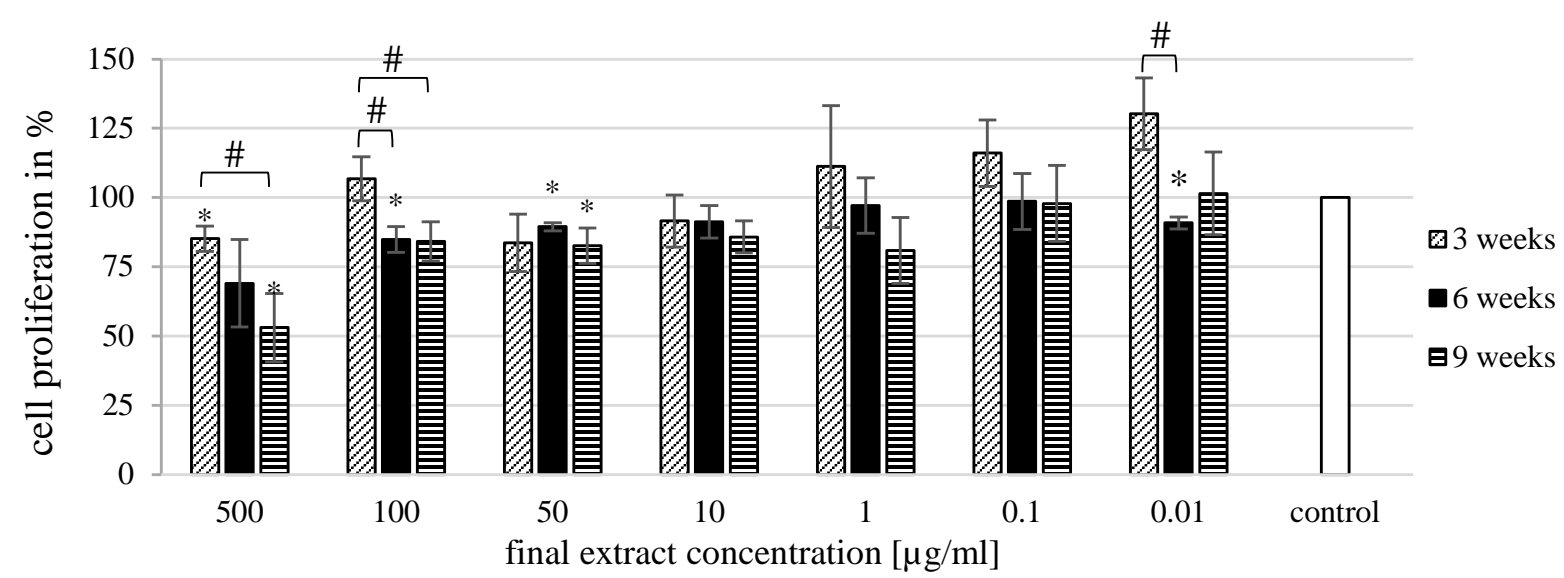

Figure 4. Effect of various concentrations of root extracts from Linum usitatissimum at various stages of maturity on the cell proliferation (BrdU test) of the MCF7 cell line. Data (mean \pm SD) represent relative BrdU uptake in \% in comparison with a negative ethanol control (100\%) and were obtained in at least 4 experiments. Asterisks $\left(^{*}\right)$ indicate significant differences between treated cells and the negative control $(P \leq 0.01)$. Hatch signs $\left(^{\#}\right)$ indicate significant differences between same concentrations of two root extracts $(P \leq 0.05)$. 


\section{Discussion}

In previous investigations, a number of phytoestrogens have been found in the flax root. We have identified, for example, the lignans secoisolariciresinol, lariciresinol, pinoresinol and matairesinol and the isoflavones genistein, daidzein and biochanin A [7].

The present results of Py-FIMS show differences in the composition between the various states of maturity of flax roots. Although all three extracts were prepared by the same method of lignan extraction, the extract of the 3-week-old flax root contained a low lignan fraction compared with the older roots. We suggest that the lignans develop during the growing period and are influenced by abiotic environmental factors. Booth et al. have described a seasonal variation of red clover isoflavones and oestrogenic activity [14].

The high contingent of lignin dimers is notable; they are the third highest fraction at $9 \mathrm{w}$. In some plants, the contents of cellulose and lignin increase within the growing season [15]. Phenolic compounds are nearly four times more prevalent at $9 \mathrm{w}$ compared with $3 \mathrm{w}$. The group includes classes in which phytoestrogens might occur (phenols, lignin/lignan-monomers, lignin dimers, flavonoids, lignans). Therefore, the stronger inhibition of cell proliferation is possibly the result of the higher content of potential phytoestrogens in the older $9 \mathrm{w}$ root. For many isolated phytoestrogens, anti-cancerous effects have been documented in vitro and in vivo. Secoisolariciresinol, matairesinol [16] and genistein [17] are known to inhibit cell growth in MCF7 cell cultures. Several animal studies have shown a reduction of tumour growth, e.g. for daidzein [18]. However, some results are controversial [19].

Concentration-dependent biphasic effects have been described for genistein [20]. Our results demonstrate a proliferating influence after incubation with the 3-week-old root extract, mainly at lower concentrations. Thus, a low concentration of phytoestrogens from younger roots might cause oestrogenic effects, with anti-oestrogenic effects being produced by extracts at higher concentrations and from older roots. This could explain the high cytotoxicity without significant inhibition of cell proliferation in 3-week-old root extract.

Flax root extracts show a cytotoxic effect on oestrogen-receptor-positive breast cancer cells at high concentration levels and from all three stages of maturity. This, however, is reduced at lower concentrations and might indicate a dose-dependent interaction between the flax root extract and MCF7 breast cancer cells. The correlation between the dose of lignans and the effect dependent on the status of oestrogen-receptor has been described in many in vitro studies [21]-[23]. The thermograms and mass spectra of $3 \mathrm{w}$ and $9 \mathrm{w}$ extracts exhibit a greater resemblance to each other than to those of the $6 \mathrm{w}$ root extract. The cytotoxic effects seem to confirm the Py-FIMS results. For $3 \mathrm{w}$ and $9 \mathrm{w}$ extracts, a higher percentage of dead cells could be measured.

The maturity grade of plants or their various parts is thus important for the development, quality and quantity of secondary metabolites and results in different biological effects on breast cancer cell growth. These results are promising and make further research into new methods for the prevention and adjuvant therapy of breast cancer with products from endemic plants worthwhile. In order to determine the extent of the potential of flax roots in cancer therapy, however, more in vitro and in vivo studies are necessary. Further analyses will also be needed to classify the substance classes into their chemical compounds.

\section{Acknowledgements}

The authors thank Mrs. E. Greschkowitz and Mrs. C. Bauer for technical assistance.

This work was supported by The Deutsche Krebshilfe, Project No.: 107820.

\section{References}

[1] Kuiper, G.G., Carlsson, B., Grandien, K., Enmark, E., Häggblad, J., Nilsson, S., Nilsson, S. and Gustafsson, J.A. (1997) Comparison of the Ligand Binding Specificity and Transcript Tissue Distribution of Estrogen Receptors Alpha and Beta. Endocrinology, 138, 863-870.

[2] Adlercreutz, H. and Mazur, W. (1997) Phyto-Oestrogens and Western Diseases. Annals of Medicine, 29, 95-120. http://dx.doi.org/10.3109/07853899709113696

[3] Horn-Ross, P.L., Barnes, S., Lee, M., Coward, L., Mandel, J.E., Koo, J., John, E.M. and Smith, M. (2000) Assessing Phytoestrogen Exposure in Epidemiologic Studies: Development of a Database (United States). Cancer Causes \& Control, 11, 289-298. http://dx.doi.org/10.1023/A:1008995606699

[4] Dambroth, M. and Seehuber, R. (1988) Flachs_Züchtung, Anbau, Verarbeitung. Ulmer, Stuttgart.

[5] Diepenbrock, W., Fischbeck, G., Heyland, K.U. and Knauer, N. (1999) Spezieller Pflanzenanbau. Ulmer, Stuttgart. 
[6] Düll, R. and Kutzelnigg, H. (2005) Taschenlexikon der Pflanzen Deutschlands. Quelle \& Meyer, Wiebelsheim.

[7] Abarzua, S., Szewczyk, M., Gailus, S., Richter, D.-U., Ruth, W., Briese, V. and Piechulla, B. (2007) Effects of Phytoestrogen Extracts from Linum usitatissimum on the Jeg3 Human Trophoblast Tumour Cell Line. Anticancer Research, 27, 2053-2058.

[8] Luyengi, L., Suh, N., Fong, H., Pezzuto, J. and Konghorn, D. (1996) A Lignan and Four Terpenoids from Brucea javanica That Induce Differentiation with Cultured HL-60 Promyelotic Leukemia Cells. Phytochemistry, 43, 409-412. http://dx.doi.org/10.1016/0031-9422(96)00258-0

[9] Matscheski, A., Richter, D.-U., Hartmann, A.M., Effmert, U., Jeschke, U., Kupka, M.S., Abarzua, S., Briese, V., Ruth, W., Kragl, U. and Piechulla, B. (2006) Effects of Phytoestrogen Extracts Isolated from Rye, Green and Yellow Pea Seeds on Hormone Production and Proliferation of Trophoblast Tumor Cells Jeg3. Hormone Research, 65, 276-288. http://dx.doi.org/10.1159/000092591

[10] Schulten, H.R. and Halket, J.M. (1986) Rapid Characterisation of Biomaterials by Field Ionization. Organic Mass Spectrometry, 21, 613-622. http://dx.doi.org/10.1002/oms.1210211004

[11] Schulten, H., Simmleit, N. and Mueller, R. (1989) Characterization of Plant Materials by Pyrolysis-Field Ionization Mass Spectrometry: High-Resolution Mass Spectrometry, Time-Resolved High-Resolution Mass Spectrometry, and Curie-Point Pyrolysis-Gas Chromatography/Mass Spectrometry of Spruce Needles. Analytical Chemistry, 61, 221-227. http://dx.doi.org/10.1021/ac00178a007

[12] Hempfling, R., Simmleit, N. and Schulten, H.R. (1991) Characterization and Chemodynamics of Plant Constituents during Maturation, Senescence and Humus Genesis in Spruce Ecosystems. Biogeochemistry, 13, 27-60. http://dx.doi.org/10.1007/BF00002875

[13] Hempfling, R. and Schulten, H.R. (1991) Pyrolysis-(Gas Chromatography/) Mass Spectrometry of Agricultural Soils and Their Humic Fractions. Zeitschrift für Pflanzenernährung und Bodenkunde, 154, 425-430.

http://dx.doi.org/10.1002/jpln.19911540606

[14] Booth, N.L., Overk, C.R., Yao, P., Totura, S., Deng, Y., Hedayat, A.S., Bolton, J.L., Pauli, G.F. and Farnsworth, N.R. (2006) Seasonal Variation of Red Clover (Trifolium pratense, L. fabaceae) Isoflavones and Estrogenic Activity. Journal of Agricultural and Food Chemistry, 54, 1277-1282. http://dx.doi.org/10.1021/jf052927u

[15] Godin, B., Lamaudière, S., Agneessens, R., Schmit, T., Goffart, J.P., Stilmant, D., Gerin, P.A. and Delcarte, J. (2013) Chemical Characteristics and Biofuels Potentials of Various Plant Biomasses: Influence of the Harvesting Date. Journal of the Science of Food and Agriculture, 93, 3216-3224. http://dx.doi.org/10.1002/jsfa.6159

[16] Abarzua, S., Serikawa, T., Szewczyk, M., Richter, D.U., Piechulla, B. and Briese, V. (2012) Antiproliferative Activity of Lignans against the Breast Carcinoma Cell Lines MCF 7 and BT 20. Archives of Gynecology and Obstetrics, 285, 1145-1151. http://dx.doi.org/10.1007/s00404-011-2120-6

[17] Theil, C., Briese, V., Gerber, B. and Richter, D.U. (2011) The Effects of Different Lignans and Isoflavones, Tested as Aglycones and Glycosides, on Hormone Receptor-Positive and -Negative Breast Carcinoma Cells in Vitro. Archives of Gynecology and Obstetrics, 284, 459-465. http://dx.doi.org/10.1007/s00404-010-1661-4

[18] Liu, X., Suzuki, N., Santosh Laxmi, Y.R., Okamoto, Y. and Shibutani, S. (2012) Anti-Breast Cancer Potential of Daidzein in Rodents. Life Sciences, 91, 415-419. http://dx.doi.org/10.1016/j.lfs.2012.08.022

[19] Ono, M., Koga, T., Ueo, H. and Nakano, S. (2012) Effects of Dietary Genistein on Hormone-Dependent Rat Mammary Carcinogenesis Induced by Ethyl Methanesulphonate. Nutrition and Cancer, 64, 1204-1210. http://dx.doi.org/10.1080/01635581.2012.718035

[20] Lin, C.C., Tsai, Y.L., Ho, C.T. and Teng, S.C. (2008) Determination of the Differential Estrogenicity of Isoflavonoids by E2-ER-ERE Dependent Gene Expression in Recombinant Yeast and MCF-7 Human Breast Cancer Cells. Food Chemistry, 108, 719-726. http://dx.doi.org/10.1016/j.foodchem.2007.11.020

[21] Mousavi, Y. and Adlercreutz, H. (1992) Enterolactones and Estradiol Inhibit Each Other's Proliferative Effect on MCF7 Breast Cancer Cells in Culture. The Journal of Steroid Biochemistry and Molecular Biology, 41, 615-619. http://dx.doi.org/10.1016/0960-0760(92)90393-W

[22] Wang, C. and Kurzer, M.S. (1997) Phytoestrogen Concentration Determines Effects on DNA Synthesis in Human Breast Cancer Cells. Nutrition and Cancer, 28, 236-247. http://dx.doi.org/10.1080/01635589709514582

[23] Welshons, W.V., Murphy, C.S., Koch, R., Calaf, G. and Jordan, V.C. (1987) Stimulation of Breast Cancer Cells in Vitro by the Environmental Estrogen Enterolactone and the Phytoestrogen Equol. Breast Cancer Research and Treatment, 10, 169-175. http://dx.doi.org/10.1007/BF01810580 